\title{
17. TRACE ELEMENT DISTRIBUTION IN DSDP SITES 372, 374, 375, AND 376 IN THE MEDITERRANEAN SEA
}

\author{
Francis Coumes and Cyrille Boltenhagen, Société Nationale des Pétroles d'Aquitaine, Pau, France
}

\section{INTRODUCTION}

In order to investigate the geochemistry of Tertiary sediments in the Mediterranean Sea, a series of DSDP samples from Sites $372,374,375$, and 376 were analyzed by UV spectrometry (quantometer). Samples from Site 372 were also analyzed by X-ray diffraction.

In this investigation we attempted to isolate the factors controlling the chemistry of the sediments and to relate these factors to the stratigraphic, sedimentologic, or climatic variations in the sedimentary environment. The record of these variations is recognized in the sediments and described by other scientists (Mélières et al., this volume).

\section{METHODS}

\section{Bulk Mineralogy, X-Ray Diffraction (Site 372 only)}

The bulk mineralogy was analyzed by X-ray diffractometry on isogranulometric powder of the total sample. Results (calcite, dolomite, and quartz content) are given below in percentages of total rock (\% weight).

\section{Clay Minerals Determination (Site 372 only)}

The clay mineral composition was determined on the basis of X-ray patterns, and the percentages of the components were estimated from the peak heights. These patterns were obtained on the granulometric fraction less than $5 \mu$ size of the carbonate-free residue.

\section{Trace Elements by UV Spectrometry (Sites 372,} 374,375 , and 376)

Major and trace elements were analyzed by UV spectrometry on the clay fractions after ignition at $900^{\circ} \mathrm{C}$. The results given on Figures 1 to 5 are not corrected for quartz dilution which is weak in these samples ( $10 \%$ to $20 \%$ of quartz determined by X-ray diffraction).

\section{FACTOR ANALYSIS}

To further clarify the relationships between clay mineralogy and geochemistry and to emphasize interelement associations, we applied the R-mode factor analysis technique to samples from each site. Generally, R-mode factor analysis simplifies the complex relationships between the elements, by substituting a simpler correlation matrix. The method combines related elements or geochemically coherent groups of constituents into a limited number of factors which account for a part of the variance of the whole.
The influence of each factor on any particular sample (factor score) was also to be measured. The factors then were interpreted in terms of various processes responsible for the mineralogical and chemical composition of the sediment under investigation. In this study, the processes considered include sediment source, sorting during transport, redox potential and $p \mathrm{H}$ of the environment, salinity of the overlying water, and diagenetic reactions. A complete review of applications of factor analysis in geochemistry is given by Spencer et al., 1968.

\section{BULK GEOCHEMICAL DATA}

\section{Site 372}

At Site 372 the sedimentary column from bottom to top is as follows:

\section{Unit IV}

This unit of mudstone to nannofossil marlstone is 417 meters thick and is very homogeneous. The bulk mineralogy shown on Figure 1 indicates an average of $20 \%$ calcite. Dolomite is present everywhere and represents about $10 \%$ of the whole unit. Quartz occurs throughout and varies between $15 \%$ and $10 \%$. The most characteristic feature is the large amounts of clays and heavy minerals. This clay and heavy mineral fraction attains up to $60 \%$ of the bulk minerals and corresponds to the insoluble residue remaining after treatment in HCL. This fraction reflects both allochthonous and autochthonous sediment in a marine environment.

\section{Clay Composition}

The clay fraction is primarily illite which is the most abundant clay mineral (up to 55\%). Chlorite occurs frequently (from $20 \%$ to $30 \%$ ) and smectite is scarce and unequally distributed (up to 20\%). Mixed-layered clay minerals comprise about $10 \%$ of the clay group. This clay mineral association may indicate cool climate during the Burdigalian (Millot, G., 1964).

\section{Minor and Trace Elements}

The distribution of most minor elements is largely controlled by the clay minerals composition. We observe a clearly relationship between boron and vanadium, which closely correlates with chronium and nickel. All these elements belong to the "lithophilic group." The parallel variation of vanadium, chromium, and nickel, is often related to a chemical alteration of basic materials (ferromagnesian minerals 


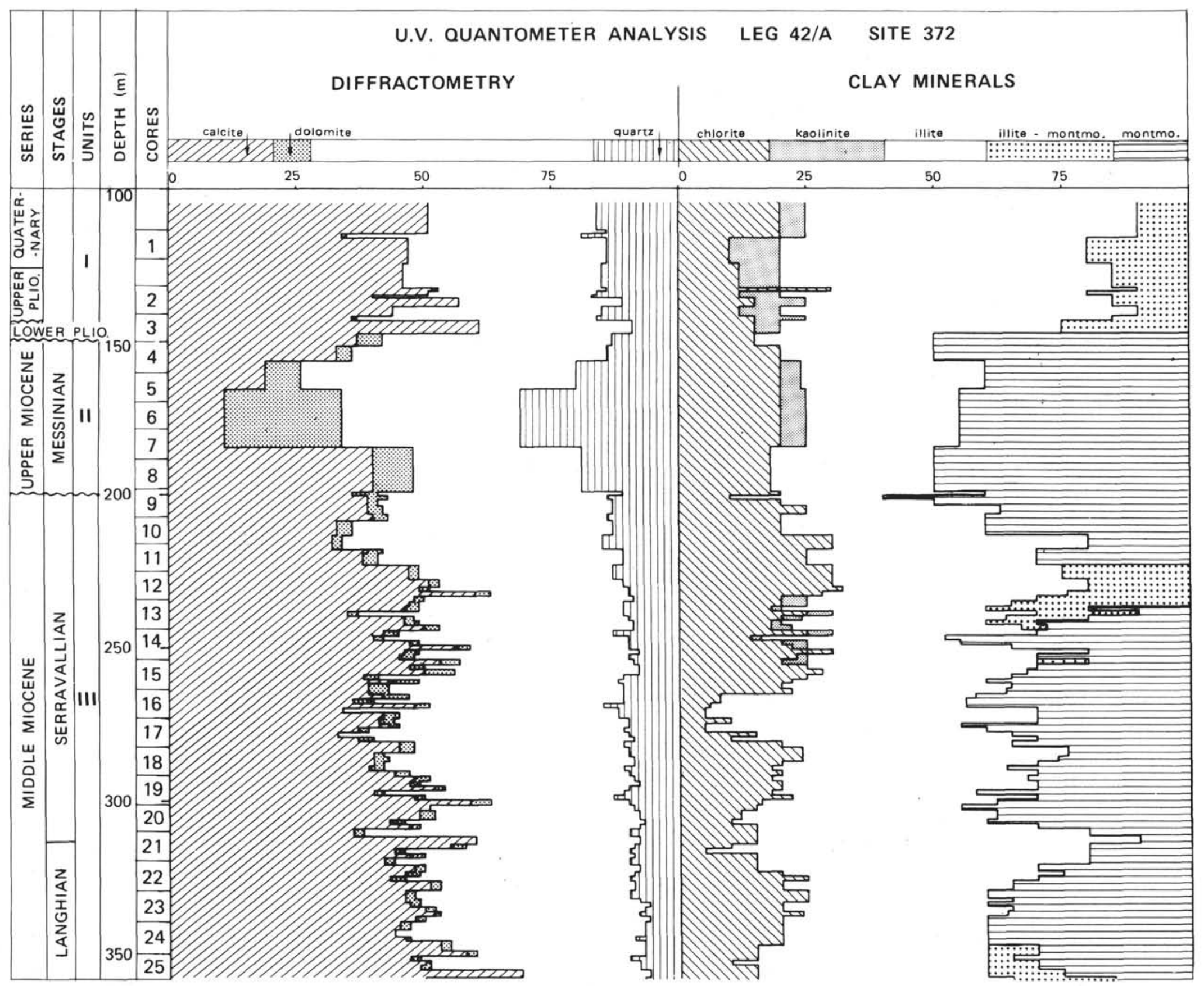

Figure 1. Variations in diffractometry and clay mineral analyses against depth in hole, Site 372. 


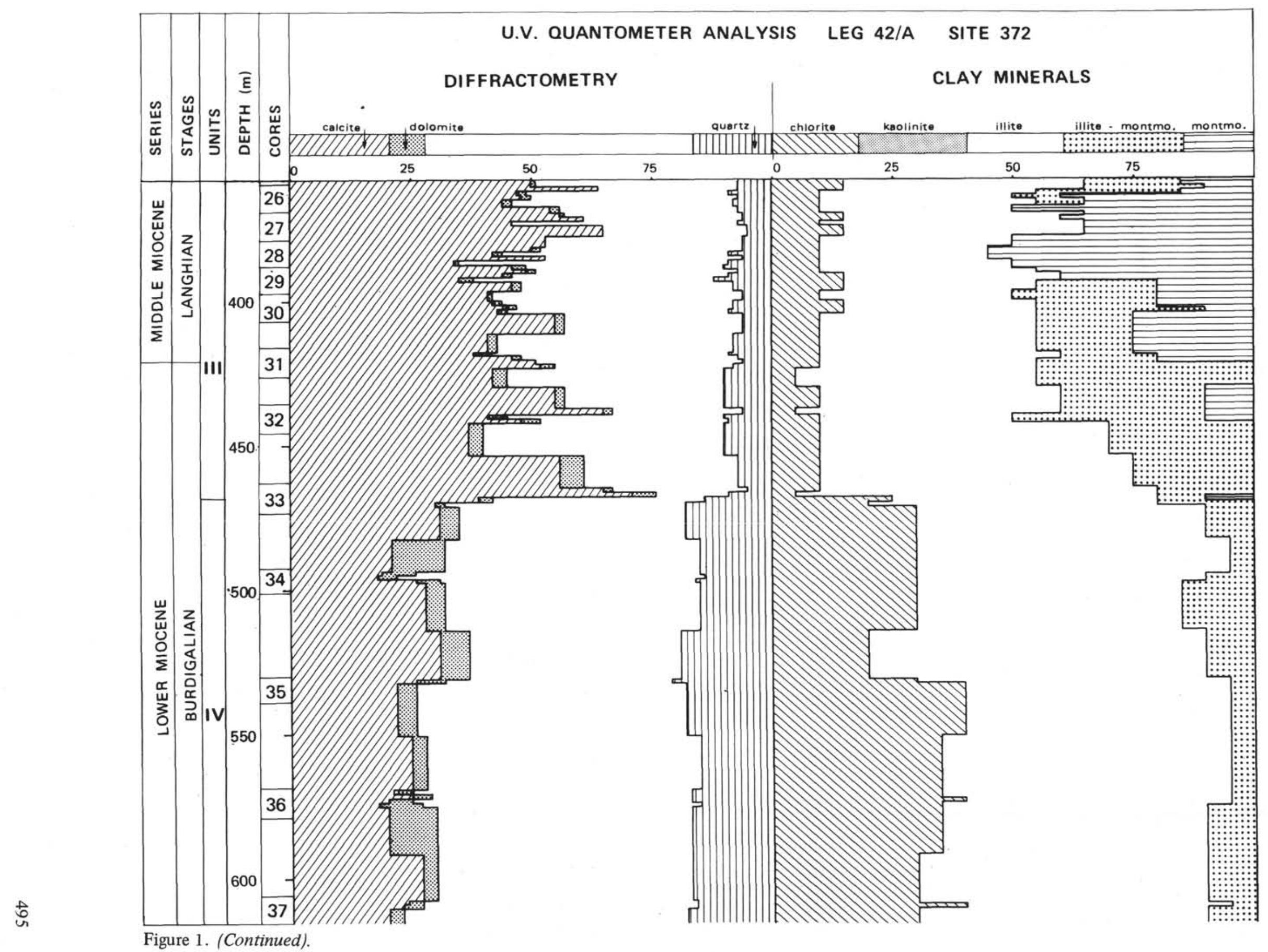




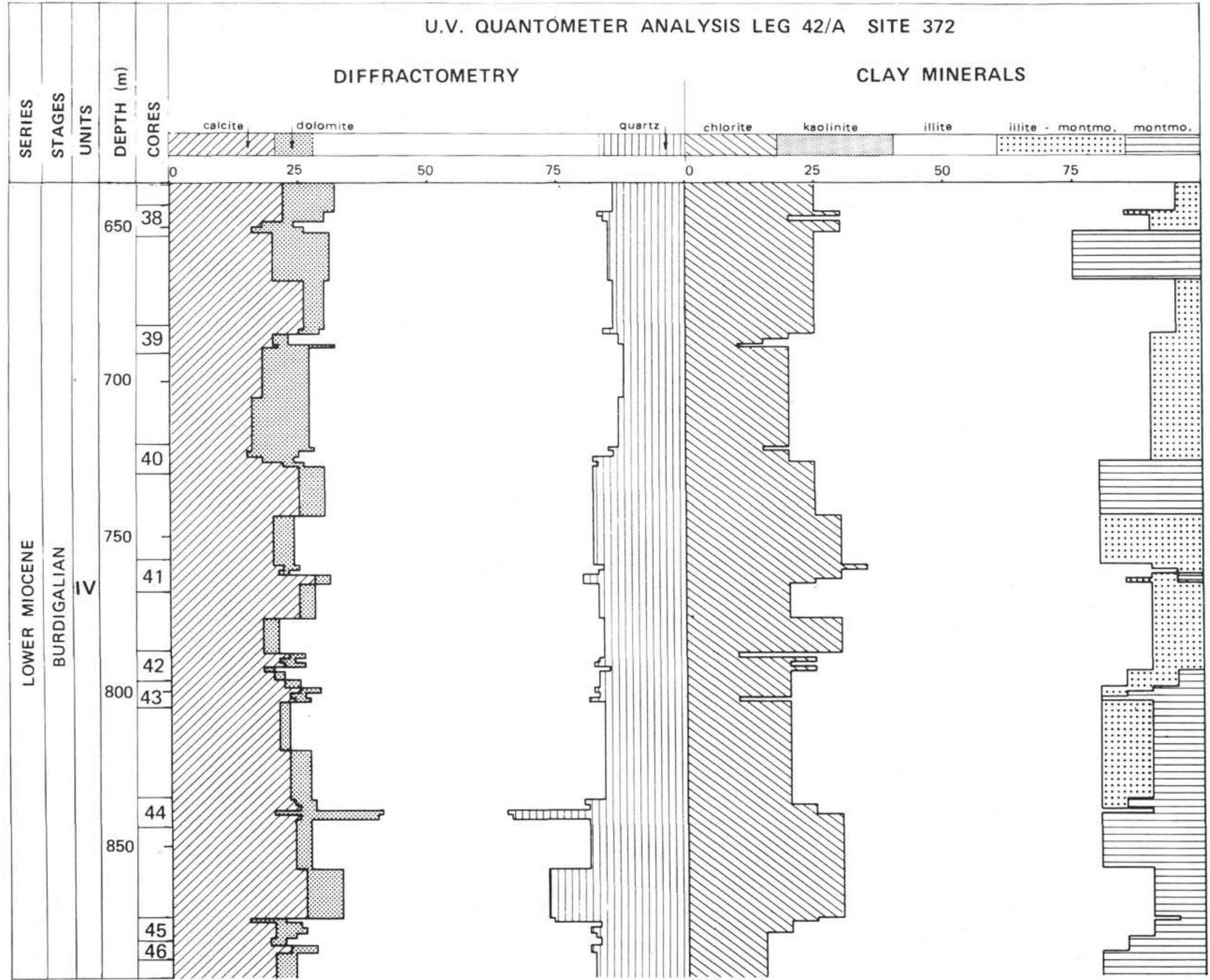

Figure 1. (Continued). 


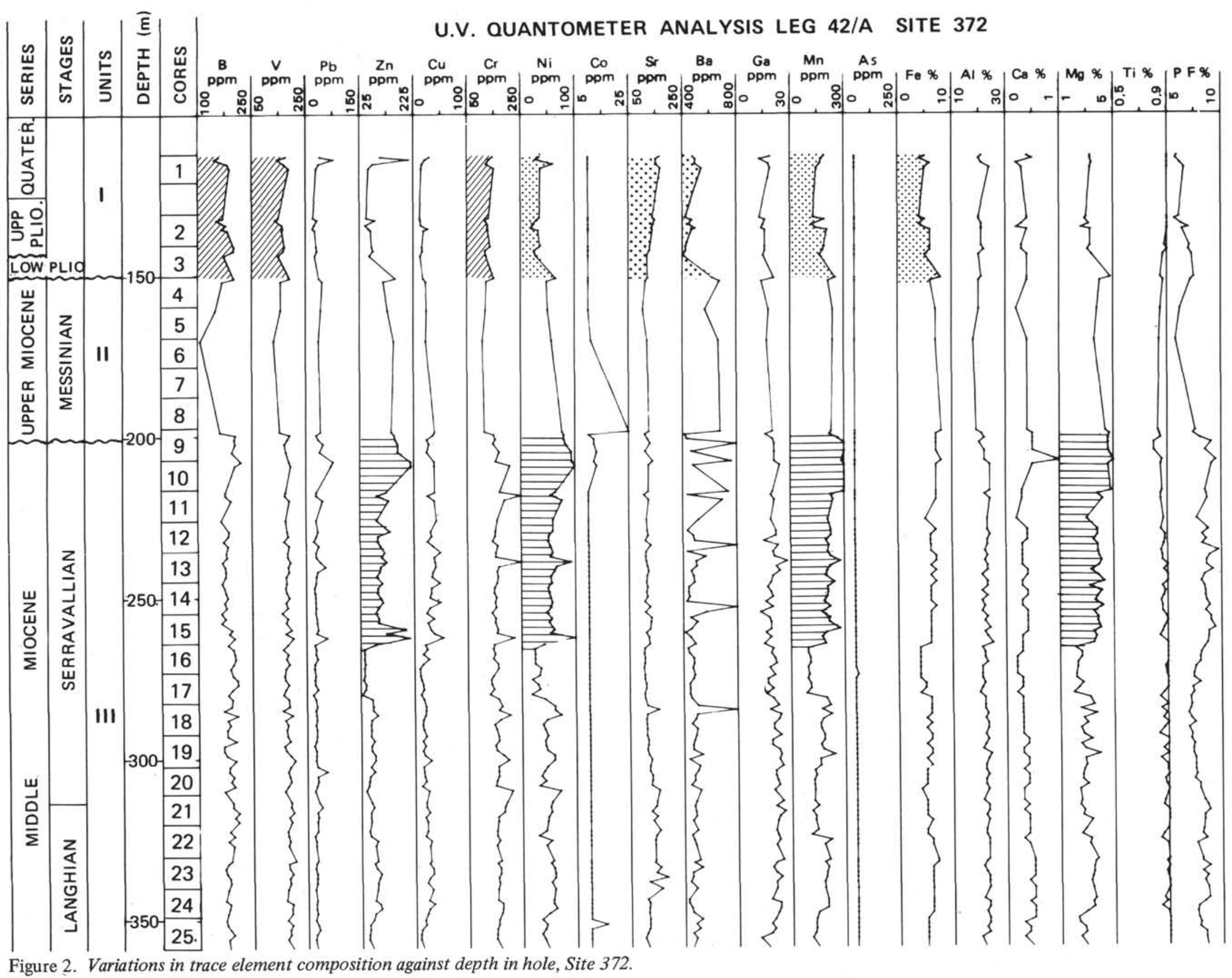

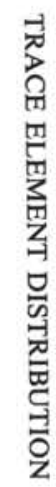




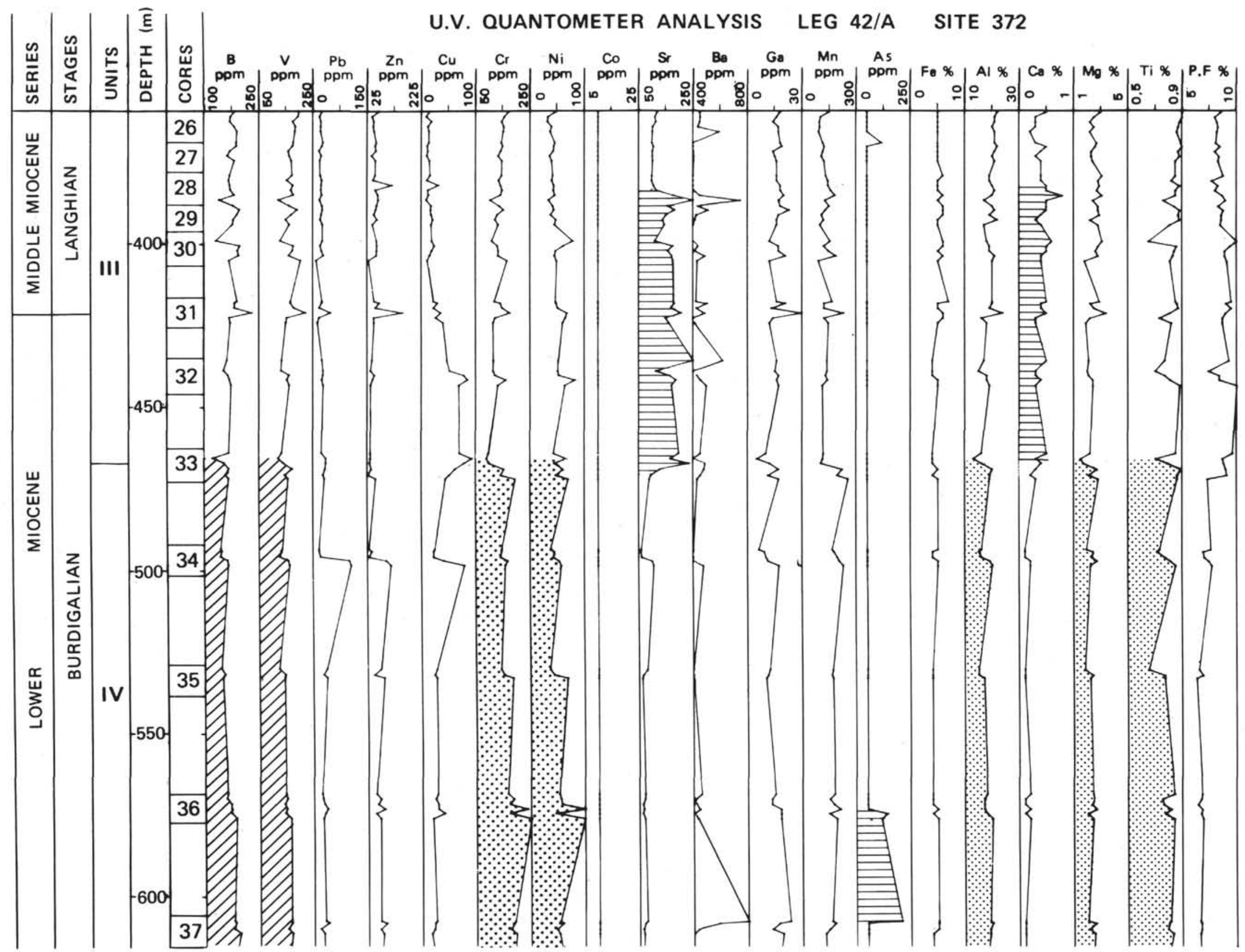


| $\operatorname{s|}|\overline{\underline{\varepsilon}}| \quad$ U.V. QUANTOMETER ANALYSIS LEG 42/A SITE 372

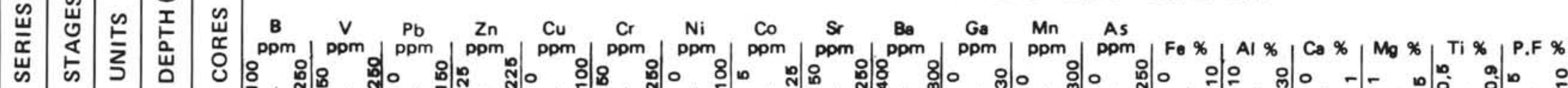

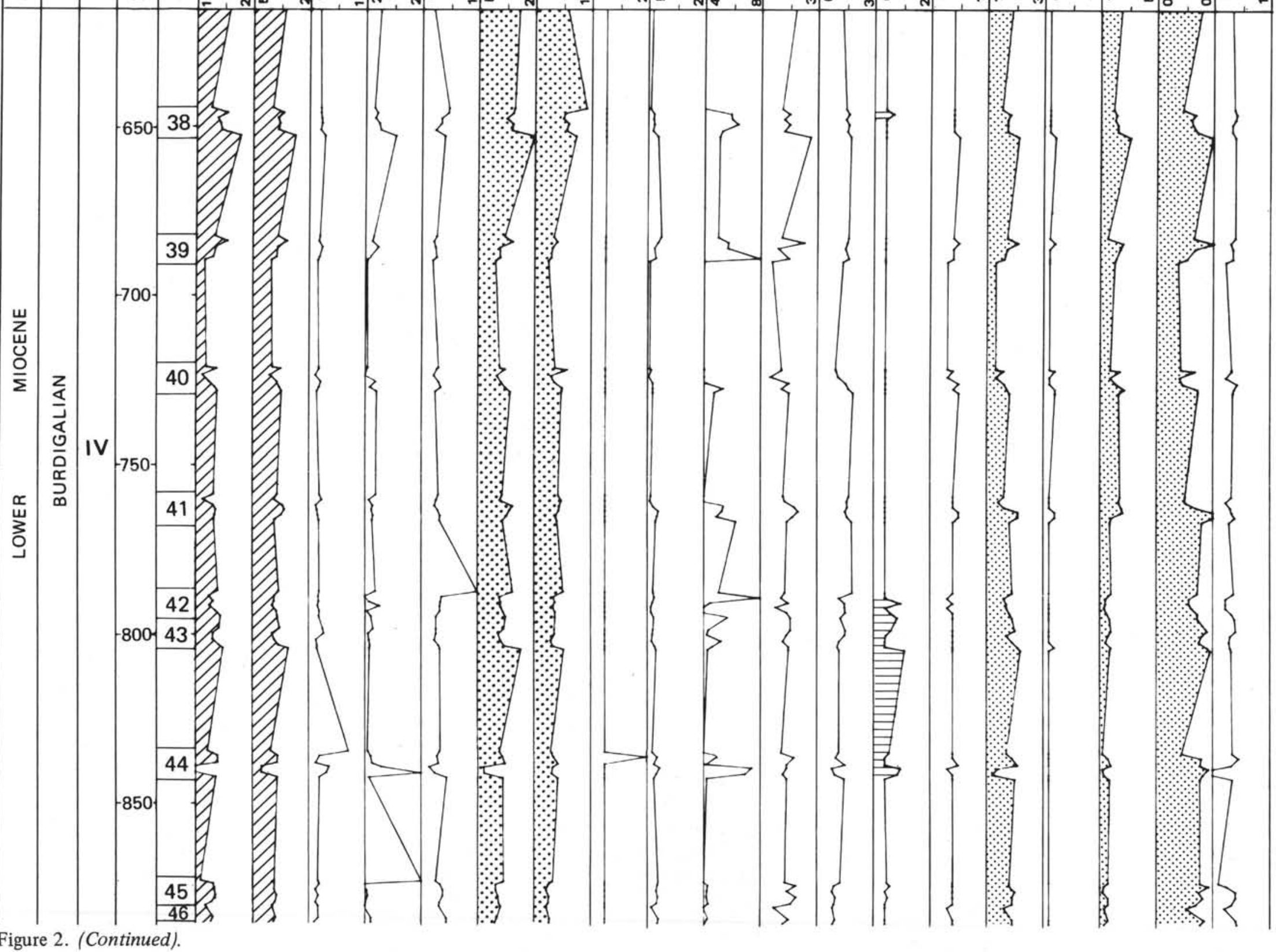

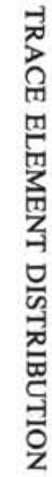
Figure 2. (Continued). 

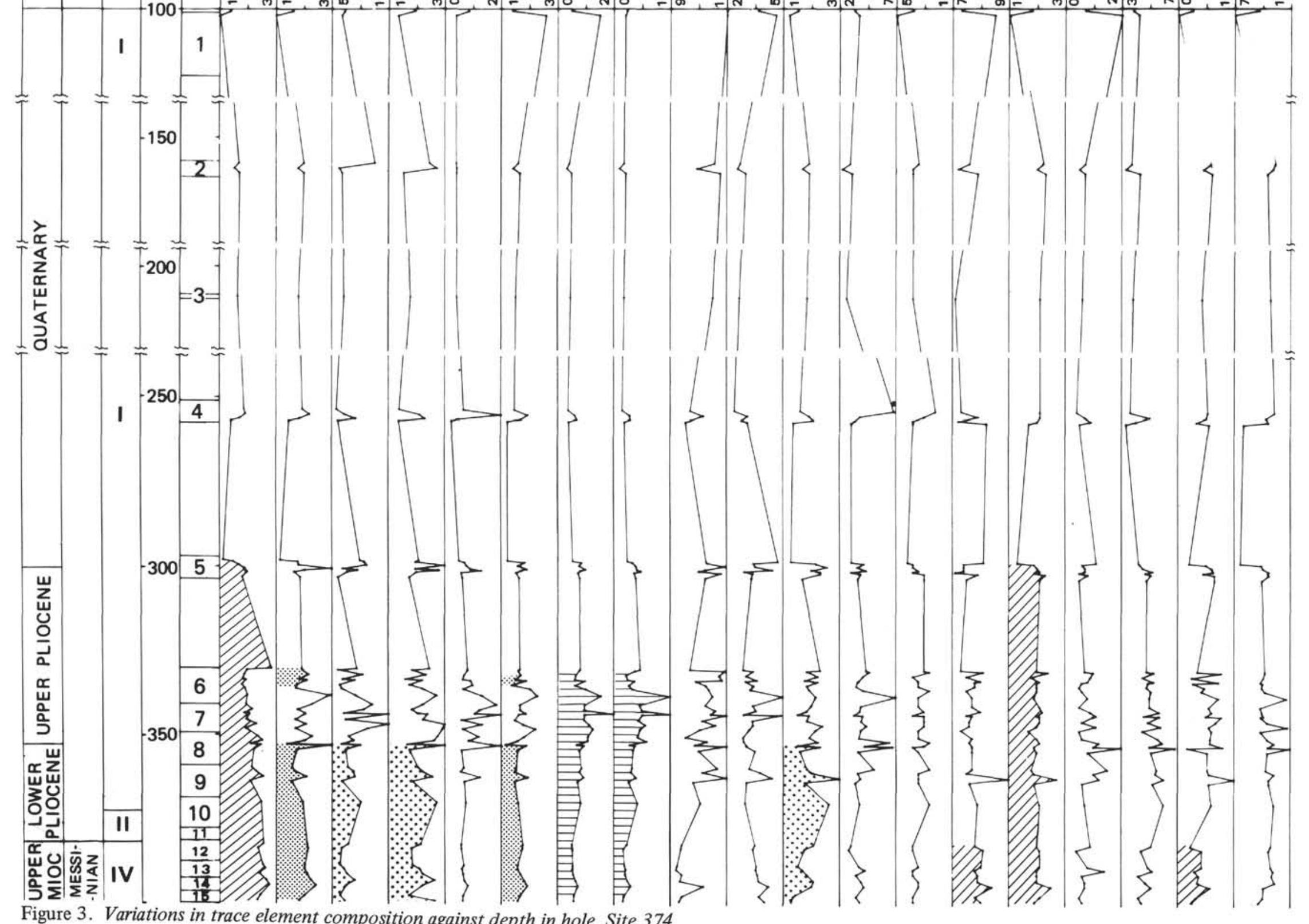

Figure 3. Variations in trace element composition against depth in hole, Site 374. 
U.V. QUANTOMETER ANALYSIS LEG 42/A SITE 375

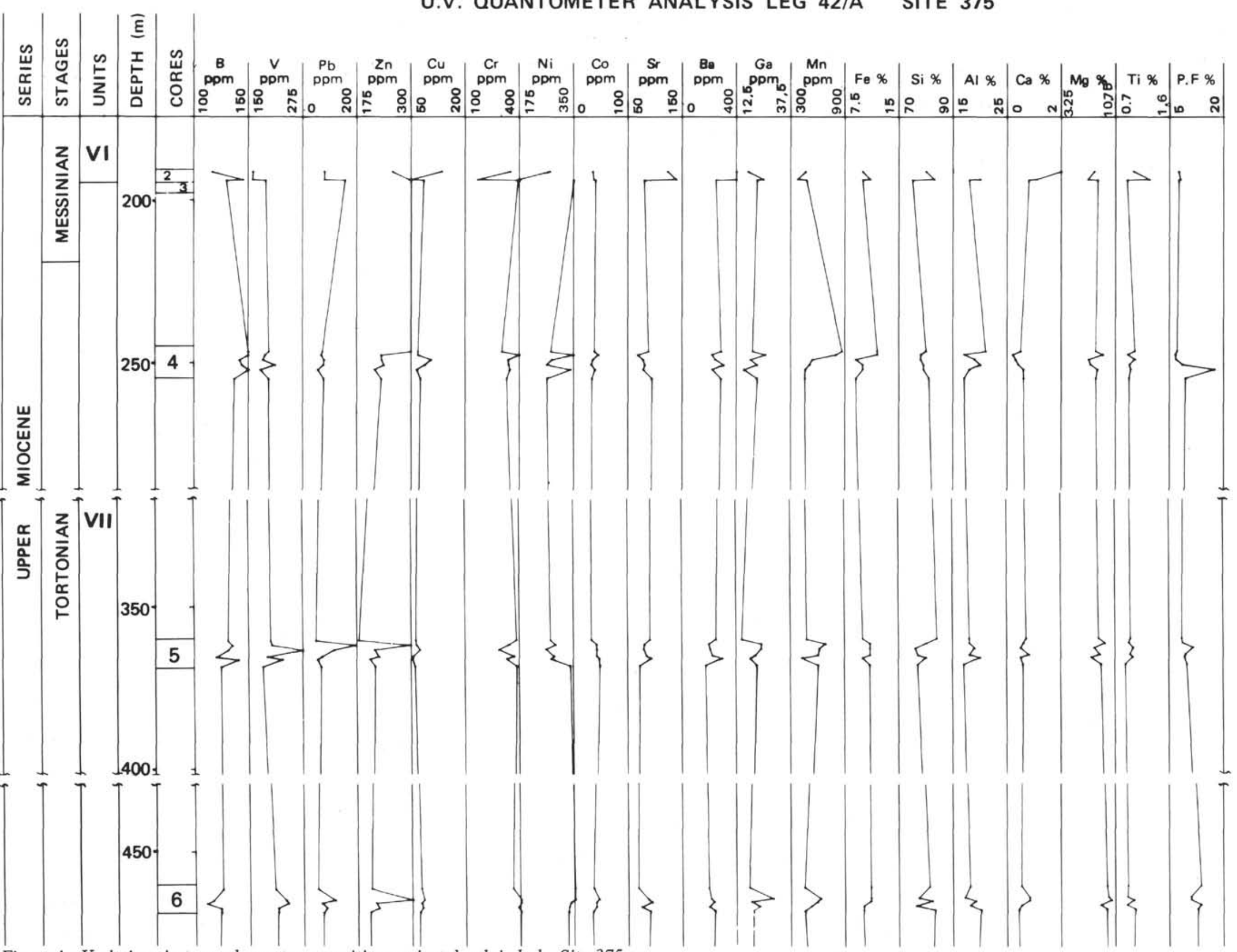

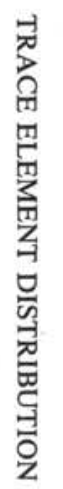

Figure 4. Variations in trace element composition against depth in hole, Site 375. 


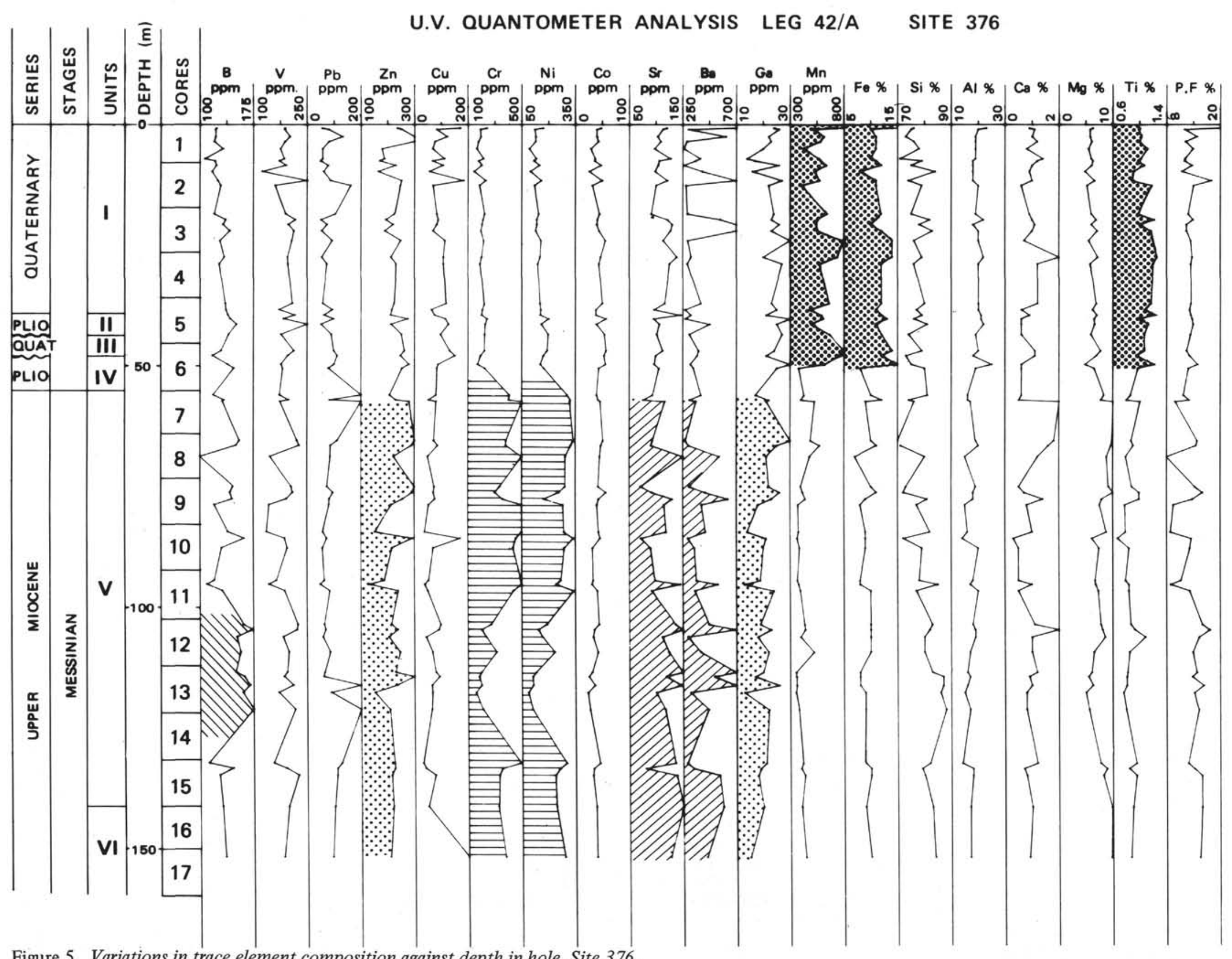

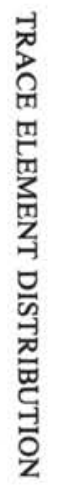


such as amphiboles, hypersthene) which are transformed into chlorite by permanent flushing. However, the $\mathrm{Ni} / \mathrm{C}_{\mathrm{o}}$ ratio (ranging from 5 to 10 ) seems to indicate a mixed origin for the sedimentary material (partly acid, partly basic). Vanadium, chromium, and nickel have an ionic radius very similar to the radius of $\mathrm{Mg}^{++}(0.80 \AA)$ which is a main constituent of chlorite. This similarity permits these metallic elements to replace the $\mathrm{Mg}^{++}$in crystal structures (D. Caroll, 1958).

The boron values, corrected from quartz dilution, indicate a normal marine environment.

Some high arsenic values are recorded from Cores $36,37,42,43$, and 44 . Arsenic content is apparently completely independent of the other elements (except barium).

Aluminum, titanium, magnesium, and gallium appear to parallel the lithologic variations along the sedimentary column. We assume that these "lithophilic" elements reached the basin as hydroxides. The low iron content and the apparent unrelated variations of $\mathrm{Fe}_{2} \mathrm{O}_{3}$ and $\mathrm{TiO}_{2}$ seem to indicate that titanium is not incorporated as a residual product like illmenite $(\mathrm{Ti}$, $\mathrm{Fe})_{2} \mathrm{O}_{3}$, for example.

Also of interest is the high zinc content in Cores 44 and 45 which is associated with a higher quartz content. This indicates that zinc reached the depositional basin as a detrital oxide (Hirst et al., 1971).

From these data we conclude that the bulk sediment is inherited from a mesocratic source which was flushed constantly by meteoric waters in a cold and humid climate. The clay fraction reached the marine basin as a suspended load where it was mixed with pelagic foraminifera and calcareous nannoplankton.

\section{Unit III (Langhian-Serravallian; $267 \mathrm{~m}$ thick)}

This unit is composed of nannofossil marls and limestones. Its upper limit is marked by a striking change in the bulk mineralogy and clay content of the sediments. Calcite is more abundant than in Unit IV (up to $60 \%$ ), and dolomite is rare. The calcite/dolomite ratio is greater than 20. Quartz is less abundant and the insoluble residue is depleted compared to Unit IV $(<50 \%)$. There is a decrease of the terrigenous components and an increase in biogenic components which form the bulk of the sediment (foraminifera, nannofossils). The pelagic fraction constitutes a much greater proportion of the sediment than it did in Unit IV.

\section{Clay Composition}

As in Unit IV, the clay mineral composition of Unit III reflects changes in the origin of the material. Chlorite is depleted relative to Unit IV. It is abundant in the upper part of Unit III (up to $30 \%$ ), and decreases regularly downwards. Illite is also less abundant $(<50 \%)$. In contrast, smectite and mixed-layered clays are much more significant here than in Unit IV. A progressive change occurs between Units IV and III with a depletion of mixed-layered clay minerals and an increase in smectite in Unit III. Kaolinite is present in small amounts in the upper part of the unit (Cores 13, $14,15)$.

\section{Minor and Trace Elements}

Boron values are stable which indicates an open marine, slightly euxinic, environment (between Cores 16 to 22 ).

Zinc and nickel concentrations are high in the upper part of the unit, and decrease slowly downwards. Manganese, magnesium, and (?)copper appear to follow a similar trend. We assume that concentrations of all elements must be related to the chlorite content which also decreases regularly from the top to the bottom of the unit.

High values of strontium occur in the lower part of the unit between Cores 28 and 33. A similar slight increase in the calcium content occurs in the clay fraction. Furthermore, an increase in the loss at ignition occurs downward and is associated with a slight depletion of $\mathrm{TiO}_{2}$ and $\mathrm{Al}_{2} \mathrm{O}_{3}$ content.

We propose that these modifications correspond to a change in the clay mineral content, which is marked by greater amounts of mixed-layered clays. In such clays there is a large amount of interstitial water and a high concentration of cations (e.g., $\mathrm{Ca}^{++}$).

There is a small amount of clinoptilolite between Cores 28 to 33 (Mélières et al., this volume). This zeolitic mineral occurs frequently in porcellanites of the North Atlantic. Consequently, volcanic or submarine hydrothermal activity may be the mechanisms responsible for mineral associations. Clinoptilolite and montmorillonite constitute a very common mineralogical association in altered pyroclastic deposits.

\section{Unit II (Messinian; 51 m of gypsum and dolomitic marl)}

This unit contains a small proportion of calcite. Quartz is notably abundant (Core 6) and dolomite comprises about $18 \%$ of the sediment.

The distribution of clay minerals is completely distinct from Units IV and III. Montmorillonite is the major constituent (up to 50\%). There are no significant mixed-layered clays, and the illite content is very low compared to the other units $(<30 \%)$. Chlorite comprises $20 \%$ of the clay fraction, and kaolinite is present in cores where the dolomite content is high. The poor clay fraction could be inherited or degraded illite and chlorite. Moreover, the presence of montmorillonite seems to be the result of alteration processes in a restricted environment.

\section{Trace Elements}

Surprisingly, the boron content is lower than in the neighboring units (as low as $175 \mathrm{ppm}$, corrected for quartz dilution, Core 6). This indicates a considerable change in the hydrologic conditions of the sedimentary basin during deposition of Unit II.

The geochemistry of the other elements follows a predictable course with lower and more uniform values in Unit II than in Unit IV for vanadium, chromium, 
aluminium, which are "lithophilic" elements generally absorbed on illite.

There is a higher cobalt concentration near the base of the unit (Core 9). Cobalt concentrations which generally vary independently of the clay mineral concentrations, seems to be related to high iron content as colloidal hydroxide or stable oxide (magnetite). The parallel behavior of manganese indicates that it is more probably related to a hydroxide phase (Horowitz et al., 1976).

\section{Unit I (Pliocene-Quaternary; nannofossil marls, $150 \mathrm{~m}$ thick)}

This sequence is calcareous, contrasting with Unit II. Calcite is abundant, comprising as much as $50 \%$, and quartz comprises between $15 \%$ and $20 \%$ of the bulk sediment. The clay minerals are primarily illite with small amounts of chlorite and illite-montmorillonite. Unit I is similar to Unit III. The only difference seems to be in the presence of kaolinite in Unit I.

\section{Trace Elements}

Concentrations of vanadium and chromium, and to a lesser extent boron, fluctuate in a similar manner. They are probably "lithophilic" in relation to the clay content (Hirst et al., 1971).

Nickel, iron, and manganese are closely related and mark a hydroxide phase. Concentrations of strontium and barium decrease from the top to the bottom of the unit.

The concentrations of the other trace elements are close to their mean values.

The boron content, after correction for quartz dilution correction, varies between $250 \mathrm{ppm}$ and $300 \mathrm{ppm}$ and corresponds to high salinities.

\section{Site 374}

Sedimentary Column (Mélières et al., this volume)

\section{Unit III (Messinian, $125 \mathrm{~m}$ of dolomitic mudstone)}

The hole did not reach the lower limit of this unit. Only the upper part of the Messinian was drilled which is dolomitic mudstone.

A high smectite content marks this unit and dolomite constitutes as much as $45 \%$ of the bulk sample. Moreover, chlorite and illite form an appreciable part of the clay content (up to $40 \%$ ). The presence of boron in relation to sulfate content seems to indicate a slightly restricted environment ( $>250 \mathrm{ppm})$. Boron decreases regularly up-hole until the top of the Pliocene.

\section{Unit II (lower Pliocene, $9 \mathrm{~m}$ of dolomite)}

We did not analyze samples from this unit.

Unit I (Pliocene, Quaternary, $323 \mathrm{~m}$ thick nannofossil marl and ooze or mud)

A distinct change occurs in the lithology between Cores 4 and 5. Below Core 4, the sediments are essentially calcareous (up to $78 \%$ calcite content) and clay minerals are dominated by attapulgite. The upper part of the unit (Core 4 and above) is less calcareous and attapulgite is completely absent. Instead, the smectite content is high, up to $70 \%$. Illite, kaolinite, and in smaller amounts, chlorite are present.

\section{Correlation Matrix}

We have run two correlation matrices. The first was applied to all the samples analyzed; the Messinian samples were eliminated from the second matrix. We obtained the same factors from both matrices which are as follows:

1) Vanadium-Chromium-Aluminium-Loss at ignition. The score of this factor is positive in the Quaternary (Cores 1 to 4 ) and in the Messinian. This indicates that ionic bonds link these "lithophilic" elements to the montmorillonitic and illitic substrate.

2) A strong correlation appears between nickel and cobalt throughout the sedimentary column. Nickel and cobalt are "siderophilic" elements and are commonly covariant. This factor shows a positive score between Cores 4 and 8 which correspond to the upper Pliocene. We suppose that the concentrations of these elements relate to the attapulgite content.

3) The correlation matrix analysis shows that strontium and calcium are linked in the same factor whose response is positive for Cores 8 and 9. These high values of strontium correspond to an environment saturated in calcium. The ionic capacity exchange of the clays, particularly smectite, permits $\mathrm{Ca}^{++}$to be incorporated into the clay structure. Strontium follows the same path.

4) A factor composed primarily of silica (and smaller amounts of barium) varies positively in the Messinian unit. This factor is more difficult to explain, but we assume that siliceous clays (illite + mixedlayered + smectite) are responsible for the high silica content.

\section{Site 375}

\section{Summary of the Sedimentary Column (Mélières et al., this volume)}

The lower and middle Miocene (Units IX to VIII, $222 \mathrm{~m}$ thick) are nannofossil marlstone and limestone. The clay fraction is essentially smectite with lesser amounts of attapulgite and chlorite and trace amounts of illite. Kaolinite is present in Cores 10 and 11 (Unit $\mathrm{X}$ ). The Tortonian (Unit VII, $380 \mathrm{~m}$ thick) is very uniform and is composed of dolomitic marlstone with interbedded siltstone and sandstone.

\section{Correlation Matrix}

$\mathrm{R}$-mode factor analysis of the data for the clay mineral component produced six factors which together account for $78 \%$ of the total variability. The major factor groups nickel, chromium, and magnesium and in the opposite sense aluminum, titanium, and strontium. This factor reflects the chlorite/kaolinite ratio which varies from 30 in the Tortonian to 1 in the middle Miocene. The presence of chlorite seems to explain the high concentrations of $\mathrm{Cr}, \mathrm{Ni}$, and $\mathrm{Mg}$ 
which are normally present in a direct relationship to the alteration of pyroxene and amphibole of basic and ultrabasic rocks.

A second factor concerns boron exclusively and marks a depletion of this element in two intervals: Cores 5, 6, 7 (lower Tortonian) and Cores 10 and 11 (middle Miocene).

Another factor groups manganese and iron and reacts positively from Core 8 to Core 11 (middle Miocene). This factor corresponds to a hydroxide phase as indicated by the associated elements $(\mathrm{Ni}, \mathrm{Cu}$, Co). Note that the carbonate content of this interval is very high (up to $98 \%$ ) and that the highest values of iron could be related to the color of the sediment (Orbulinico Rosso).

The values of the other elements are common, except for copper and cobalt which show marked concentrations in the middle Miocene sediments associated with important loss at ignition. This suggests that these two metallic elements are concentrated in an aqueous phase corresponding to a higher smectite content.

A medium negative $\mathrm{SiO}_{2}$ loading is compensated for by opposite loading for zinc and gallium. This factor could be related to the clay fraction composition.

\section{Site 376}

Lower Neogene sediments were recovered in this hole. From the bottom to the top the sedimentary column is as follows (Mélières et al., this volume).

Unit IV (Messinian, $176 \mathrm{~m}$ thick)

This unit is anhydrite and halite in the lower part and gypsum and green dolomitic marlstone in the upper part. The clay fraction is dominated by smectite.

\section{Unit V (Messinian, $86 \mathrm{~m}$ thick)}

This unit is marlstone with interbedded graded sandstone and siltstone. The carbonate content is high (up to $40 \%$ ). The clay fraction is primarily smectite, with some chlorite and attapulgite. The presence of the attapulgite, moreover, constitutes the most significant aspect of the clay mineral content (up to $30 \%$ ).

\section{Units IV, III, II, I (Pliocene-Quaternary)}

These units are nannofossil marls with interlayered sapropels. The clay fraction is essentially smectite.

\section{Correlation Matrix}

We detected a factor grouping magnesium, nickel, and chromium. The factor reacts positively from Core
1 to Core 6 . We assume that these elements mark a hydroxide phase and the presence of kaolinite, in lesser amounts, in Pliocene-Quaternary deposits. Fe and Mn principally reflect the abundance of authigenic constituents and $\mathrm{Al}_{2} \mathrm{O}_{3}$ and $\mathrm{TiO}_{2}$ reflect the abundance of detrital components.

A factor grouping boron, vanadium, and loss at ignition shows a marked increase in Cores 12 to 14 , where the clay fraction is formed exclusively by smectite. This interval has a high value for boron content and lower values of nickel and chromium. The behavior of these elements emphasizes the nature of the clay content (smectite dominating) (Curtis, 1969).

A last factor concerns barium, strontium, and calcium. The two former elements are strongly linked and show a typical lithophilic behavior. Their high solubility and their high ionic radii are responsible for their precipitation in a carbonate phase. Thus, it appears that post-depositional migration of such elements may have occurred.

\section{Individual Behavior of Trace Elements}

Other points of interest are:

1) Copper shows high values in the PlioceneQuaternary and seems to be related to the hydroxide phase in which it is absorbed in an oxidizing environment.

2) Lead shows some concentrations (Cores 7 and 13) that could result from sulfate reduction processes.

\section{ACKNOWLEDGMENT}

The authors are indebted to L. Montadert of the Institut Francais de Pétrole for making available the samples used in this investigation, and thank SNPA and Comité d'études marines which kindly gave permission to publish this report.

\section{REFERENCE}

Caroll, D., 1958. Role of clay minerals in the transportation of iron; Geochim. Cosmochim Acta, v. 14, p.1-27.

Curtis, C. D., 1969. Trace element distribution in some British carboniferous sediments: Geochim. Cosmochim Acta, v. 33, p. 519-523.

Hirst, D. M. and Kaye, M. J., 1971. Factors controlling the mineralogy and chemistry of an upper visean sedimentary sequence from Rookhope County, Geology, v. 8, p. 37-59.

Horowitz, A. and Cronan, D., 1976. The geochemistry of basal sediments from the North Atlantic Ocean: Marine Geol., v. 20, p. 205-228.

Millot, G., 1964. Geologie des argiles: Paris (Masson).

Spencer, D. W., Degens, E. T., and Kulbicki, G., 1968. Geochemical factors governing the distribution of elements in sedimentary rocks. In Arhens, L. H., (Ed.), Origin and distribution of the elements: UNESCO. 